\title{
Investigation of corrosion fatigue cracks of steel under wetting and drying conditions
}

\author{
Lihua Liang \\ Qingdao Technical College, No. 369, Qiantangjiang Road, Huangdao \\ district, Qingdao, Shandong 266555, China
}

Received October 17, 2018

The results demonstrated that dry/wet ratio and loading frequency could significantly affect the growth rate of the corrosion fatigue cracks of steel structure. The effects of dry/wet ratio on the growth rate of cracks became smaller with the increase of the amplitude of stress intensity factor under the same loading frequency. The effects of dry/wet ratio on the growth rate of cracks became smaller with the increase of loading frequency under the same dry/wet ratio.

Keywords: corrosion fatigue, D36 steel, dry/wet ratio, crack growth.

\begin{abstract}
Проведены исследования роста коррозионных усталостных трещин стальной плиты при различных соотношениях сухой / влажной среды и различных механических нагрузках. Результаты показали, что сухое / влажное соотношение и частота нагружения могут существенно влиять на скорость роста трещин коррозионной усталости стальной конструкции. Влияние сухого / влажного соотношения на скорость роста трещин уменьшается с увеличением частоты и интенсивности напряжений. Темпы роста стальных трещин на стадии низкой интенсивности напряжений выше, чем в среде морской воды в критических условиях сухого / влажного соотношения.
\end{abstract}

Дослідження корозійних втомних тріщин сталі в умовах змочування і сушки. Lihua Liang.

Проведено дослідження зростання корозійних втомних тріщин сталевої плити при різних співвідношеннях сухого / вологого середовища і різних механічних навантаженнях. Результати показали, що сухе / вологе співвідношення і частота навантаження можуть суттєво впливати на швидкість росту тріщин корозійної втоми сталевої конструкції. Вплив сухого / вологого співвідношення на швидкість росту тріщин зменшуться зі збільшенням частоти та інтенсивності напружень. Темпи зростання сталевих тріщин на стадії низької інтенсивності напружень вище, ніж у середовищі морської води в критичних умовах сухого / вологого співвідношення.

\section{Introduction}

Steel structure is the most widely used structure in the infrastructure construction of marine engineering, but it also causes corrosion $[4,5]$. If steel structures is located on the mainland, the problem is relatively not very serious. But marine engineering are often away the mainland, which causes difficulties in maintenance equipment and traffic.Therefore long-term operation should be considered in the design.
Steel structure will be severely corroded in the long-term operation of marine engineering, and moreover the maintenance cost is high because of the aforementioned reasons. Therefore how to solve the corrosion problem of steel has become a key point in the construction of marine engineering. Liu [1] proposed a nondestructive testing technology which was based on time domain reflectometry (TDR) and could determine the location and severity of corrosion of embedded or outsourced steel bars and cables. The 
Table 1. The chemical components of D36 steel

\begin{tabular}{|c|c|c|c|c|c|c|c|c||}
\hline Component & Carbon & Manganese & Silicon & Nickel & Phosphorus & Sulfur & Copper & Chromium \\
\hline Content $\%$ & 0.15 & 1.09 & 0.28 & 0.01 & 0.014 & 0.002 & 0.01 & 0.01 \\
\hline
\end{tabular}

Table 2. The mechanical properties of D36 steel

\begin{tabular}{|c|c|c|c|c||}
\hline $\begin{array}{c}\text { Mechanical } \\
\text { properties }\end{array}$ & $\begin{array}{c}\text { Elasticity modulus, } \\
\mathrm{GPa}\end{array}$ & Yield strength, MPa & $\begin{array}{c}\text { Tensile strength, } \\
\mathrm{MPa}\end{array}$ & $\begin{array}{c}\text { Cross-section } \\
\text { elongation, \% }\end{array}$ \\
\hline Size & 211 & 416 & 525 & 24 \\
\hline
\end{tabular}

experimental results showed that the TDR based corrosion detection method could detect, locate and identify the degree of corrosion damage. Bastidas et al. [2] studied two kinds of vapor phase inhibitors, dicyclohexyl ammonium nitrite and dicyclohexylamine, and the air corrosion of low-carbon steel in an environment with relative humidity of $100 \%$ and under isothermal condition $\left(25{ }^{\circ} \mathrm{C}\right)$ and found that the corrosion rate of low-carbon steel decreased when dicyclohexyl ammonium nitrite and dicyclohexylamine existed. Zhang et al. [3] explored the inhibition effect of long-chain alkyl-substituted benzimidazole derivatives on the corrosion of mild steel in $\mathrm{HCl}$ and found that it had a favourable application prospect as an corrosion inhibitor. In this study, the growth of corrosion fatigue cracks under different dry/wet ratios was tested using three-point bending method on an MTS810 electro-hydraulic servo tester. In this paper different loading frequencies and dry/wet ratio were set in the experiment to explore the influence of alternation of dry and wet on the corrosion fatigue of steel.

The phenomenon of structural cracking and premature loss of structural action of metal structures under the interaction of mechanical stress and corrosive environment is called corrosion fatigue. Its damage to metal structure is much larger than simple fatigue or pure corrosion. Conventional metal fatigues which has limits are very difficult to happen if certain condition of stress has not been achieved. But corrosion fatigue which has no limit will happen as long as there is a certain stress condition. The process of fracture of metal structures can be divided into two stages: crack generation and crack growth. Small cracks will produce after accumulation reaches certain degree under the influence of stress change and corrosion environment; this process is the generation stage of cracks. The generated cracks continue to grow under the action of corrosion and stress, and the growth

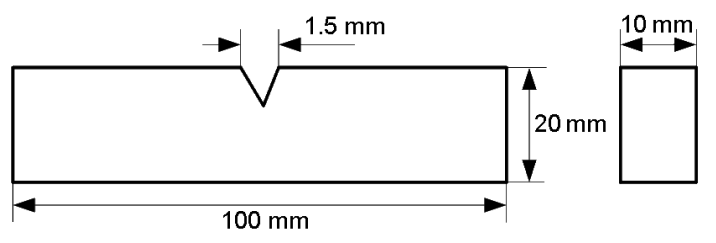

Fig. 1. The design of the test specimen

rate is increasing until metal structure fractures.

There are three kinds of factors that affect the growth rate of corrosion fatigue crack of metals, i.e., materials, corrosion environment and mechanical factors. This study focused on the effect of corrosion environment on the growth rate of corrosion fatigue cracks. The steel structure of ocean platform will be in the sea environment for a long time. Dry and wet alternation will accelerate the corrosion rate of a platform, which was because that the structure is in a hyperoxic and electrochemical environment. The influence of dry and wet alternation on corrosion rate has exceeded the influence of acidbase property and chloridion in sea water.

\section{Experimental}

D36 marine steel which is commonly used in marine engineering was taken as the material of test specimens in this study. Its chemical components [6] is shown in Table 1 , and its average mechanical properties [7] is shown in Table 2.

According to GBT6398-2000 [8], the test specimen was designed as unilateral gap, and the ratio of thickness, width and length was $8: 2: 1$. Finally the size of the test specimen was determined as $10 \times 20 \times 100 \mathrm{~mm}^{3}$. The design of the test specimen is shown in Fig. 1.

The corrosive fluid used for accelerating metal fatigue was natural seawater which had been processed by filtering. The loading device used in this experiment was a MTS810 electro-hydraulic servo testing machine [9], and the data acquisition system was IMC [10]. 
In this study, three-point bending method [11] was used in the corrosion fatigue crack growth test on the MTS810 electrohydraulic servo test machine. Marine automatic circulation system was used for simulating the alternate dry and wet marine environment[12]. In this experiment, the load waveform was sine wave, the stress amplitude was constant, $26 \mathrm{kN}$, and the stress ratio was fixed at 0.2 . The fatigue cracks were measured under the influence of different environmental factors. Alternate dry and wet and change of loading frequency were the main environmental factors considered in this study. Alternation of dry and wet was achieved by the marine automatic circulation system, and change of loading frequency was adjusted by the test machine. The crack growth test was carried out under loading frequency of $0.3 \mathrm{~Hz}, 1.5$ $\mathrm{Hz}$ and $4 \mathrm{~Hz}$ and air environment $(k=\infty)$, seawater environment $(k=0)$ and dry/wet ratio $k=1$ and 0.5 , respectively. $k$ represented the time ratio of dry and wet alteration, $k=t_{\text {air }} / t_{\text {seawater }} ; t_{\text {air }}$ meant the test time in the air environment, and $t_{\text {seawater }}$ meant the test time in the seawater. Dry and wet were alternated more than six times. The difference of alteration times between different groups was no more than 2 .

\section{Processing of experimental data}

(1) Length of cracks was measured using flexibility method [13], and it was expressed as:

$$
\begin{gathered}
U=\frac{1}{1+\left[\frac{E H X}{F} \frac{4 D}{L}\right]^{0.5}} \\
\frac{b}{D}=A_{0}+A_{1} U+A_{2} U^{2}+A_{3} U^{3}+ \\
+A_{4} U^{4}+A_{5} U^{5}
\end{gathered}
$$

where $E H X / F$ is dimensionless flexibility, $E$ is elasticity modulus, MPa, $L, D$ and $H$ are the length, width and thickness of the test specimen, respectively, $\mathrm{mm}, X$ is the opening displacement of crack $\mathrm{mm}, F$ is loading load, $\mathrm{N}, b$ is the length of crack, $\mathrm{mm}$, and $A_{0}, A_{1}, A_{2}, A_{3}, A_{4}$ and $A_{4}$ were $0.99978,-3.9505,2.9823,-3.215,51.518$ and -113.05 , respectively.

(2) The growth rate of cracks was obtained by performing local derivation fitting with seven points incremental polynomial [14], and its expression was:

$$
\left(\frac{d b}{d N}\right)_{i}=\frac{c_{1}}{B_{1}}+\frac{2 c_{2}\left(N_{1}-B_{1}\right)}{B_{2}^{2}},
$$

where $\left(\frac{d b}{d N}\right)_{i}$ is growth rate of crack on the i-th point, $c_{1}$ and $c_{2}$ are the regression parameter obtained by least square method, $\mathrm{N}$ is times of dry and wet alternation

$$
B_{1}=\frac{N_{i+3}+N_{i-n}}{2} \text { and } B_{2}=\frac{N_{i+3}-N_{i-n}}{2} \text {. }
$$

(3) The expression of stress strength factor amplitude [15] was:

$$
\begin{gathered}
\Delta K=\frac{3 \Delta F L}{2 H D^{2}} \sqrt{\pi \beta}(1.090-1.735 \beta+ \\
\left.+8.20 \beta^{2}-14.18 \beta^{3}+14.57 \beta^{4}\right),
\end{gathered}
$$

where $\Delta F$ is the difference between the maximum and minimum loads, $\mathrm{N}$, and $\beta=\frac{b}{D}$, representing dimensionless.

The curve of crack growth data- $\Delta K$ could be obtained through the above data processing.

\section{Results and discussion}

3.1 Influence of the dry/wet ratio on the growth rate of cracks under the same loading frequency

The relationships between the dry/wet ratio and the growth rate of cracks under the same loading frequency are shown in Fig. 2, 3 and 4. It could be noted from Fig. 2 that the increase of dry/wet ratio accelerated the growth of corrosion fatigue cracks when the loading frequency was 0.3 . The maximum effect of dry/wet ratio on the crack growth rate was in the low stress intensity factor amplitude stage, and the crack growth rate increased with the increase of time in the humid environment at this stage. When the stress intensity factor amplitude was about $55 \mathrm{MPa} \cdot \mathrm{m}^{0.5}$, the growth rate was basically not affected by the dry/wet ratio. The rate of growth basically coincided with the rate in air.

Fig. 3 shows that the crack growth rate under $1.5 \mathrm{~Hz}$ was reduced under the influence of the dry/wet ratio compared to that under $0.3 \mathrm{~Hz}$. The increase of the ambient humidity made the crack growth rate higher than that in the air environment, but the growth rate differed little when the dry/wet ratio was 1 and 0.5 , and moreover it was close to the growth rate in the seawater environment. In addition, Fig. 3 also shows 


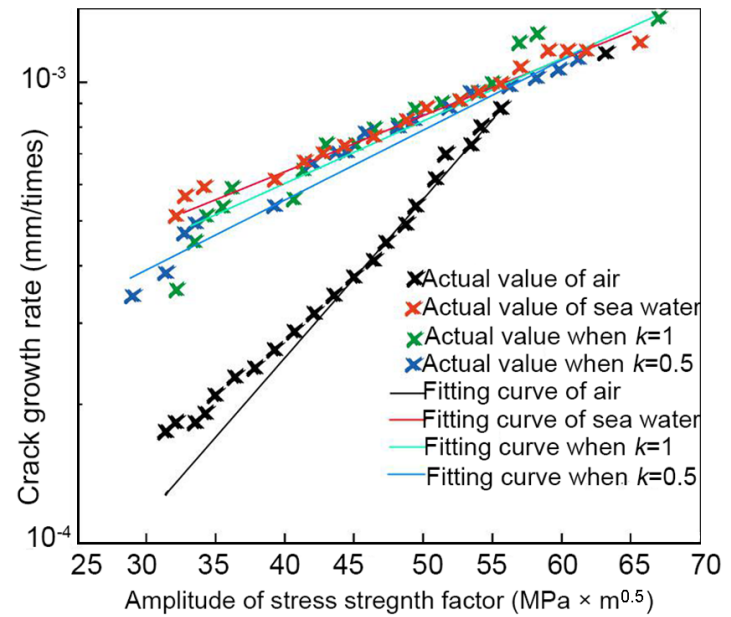

Fig. 2. Influence of the dry/wet ratio on the growth rate of cracks under $0.3 \mathrm{~Hz}$.

that the crack growth rate exceeded that in the seawater environment temporarily when the dry/wet ratio was 1 and the stress intensity factor amplitude was between 40 $\mathrm{MPa} \cdot \mathrm{m}^{0.5}$ and $50 \mathrm{MPa} \cdot \mathrm{m}^{0.5}$.

It could be noted from Fig. 4 that the expansion rate curves at different dry/wet ratios almost coincided under the loading frequency of $4 \mathrm{~Hz}$ in the low stress intensity factor amplitude interval (below 40 $\mathrm{MPa} \cdot \mathrm{m}^{0.5}$ ), indicating that the dry and wet alternation had no effect on the expansion rate at that stage. When the amplitude of stress intensity factor was greater than $40 \mathrm{MPa} \cdot \mathrm{m}^{0.5}$, the expansion rate curve in the air environment was greatly different from the curve in the humid environment. The rate of crack growth was higher in the humid environment, and the expansion rate was basically the same as that in the sea water when the dry/wet ratio was 1 and 0.5 .

The comparison between Figs. 2, 3 and 4 suggested that the crack growth rate increased firstly, then decreased, and finally approached to the rate in the seawater environment with the decrease of the dry/wet ratio when the amplitude of stress intensity factor and loading frequency were low. There was a critical dry/wet ratio; the crack growth rate was maximum under that dry/wet ratio, and the dry/wet ratio varied along with the loading frequency. This theory could explain different corrosion rates of the marine platforms at different depths, i.e., the corrosion rate increased above the sea surface and decreased under the sea surface.

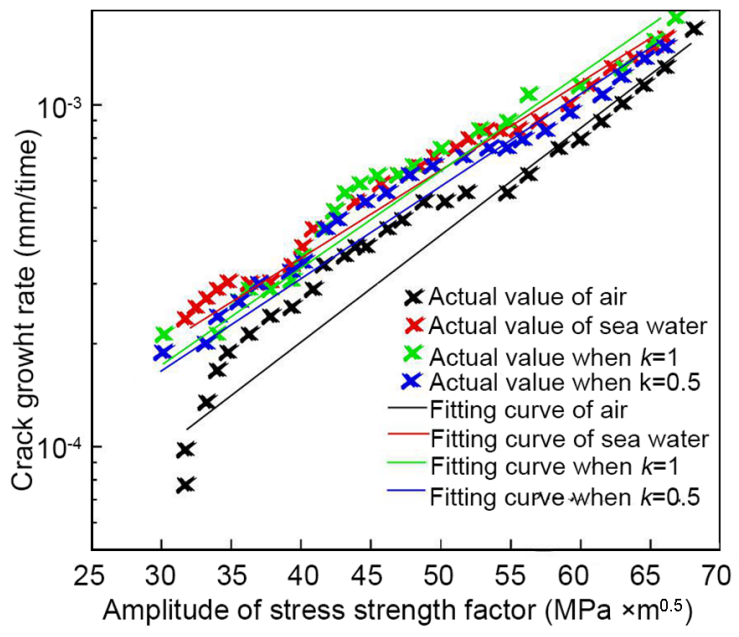

Fig. 3. Influence of the dry/wet ratio on the growth rate of cracks under $1.5 \mathrm{~Hz}$.

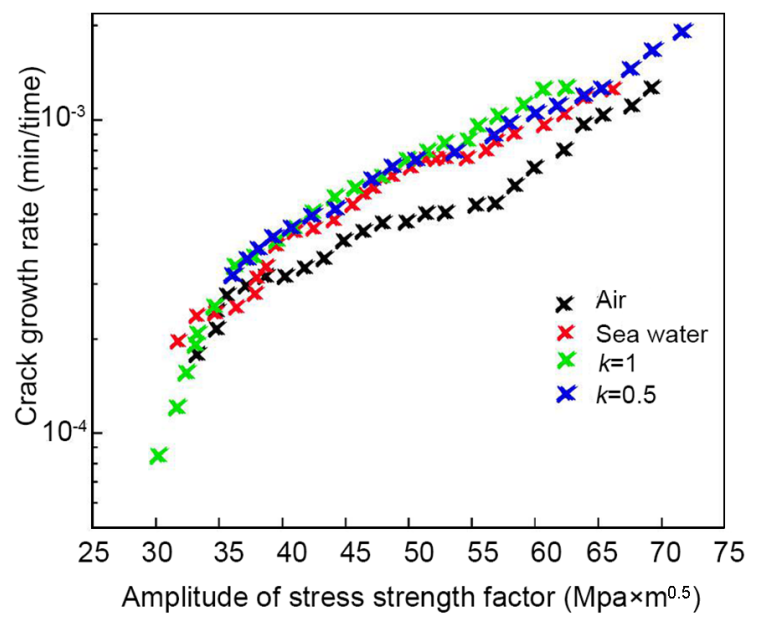

Fig. 4. Influence of the dry/wet ratio on the growth rate of cracks under $4 \mathrm{~Hz}$.

3.2 The influence of the loading frequency on the growth rate of cracks under the same dry/wet rate

Figs. 5 and 6 show the effect of the dry/wet on the crack growth rate. It was found from Figs. 5 and 6 that the growth rate of corrosion fatigue crack of steel plate under $0.3 \mathrm{~Hz}$ was much greater than that at $1.5 \mathrm{~Hz}$ and $4 \mathrm{~Hz}$ in the stage of low stress intensity factor amplitude under the same dry/wet ratio, but the difference of the growth rate between $1.5 \mathrm{~Hz}$ and $4 \mathrm{~Hz}$ was little. With the increase of the stress intensity factor amplitude, the rate of expansion under the three frequencies began to approach and tended to be consistent when the stress intensity factor amplitude was larger than $55 \mathrm{MPa} \cdot \mathrm{m}^{0.5}$.

The reason for these phenomena was the accumulated corrosion products blocked the 


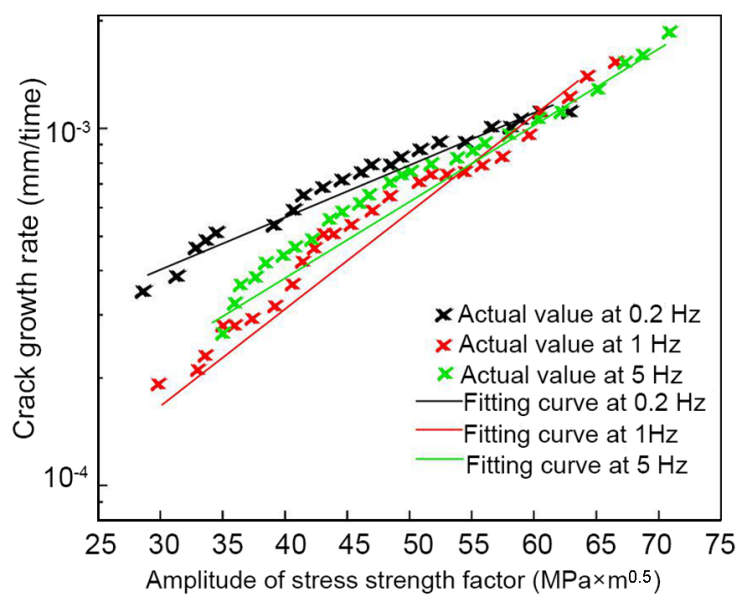

Fig. 5. The growth rate of cracks under loading frequency of $0.2,1$ and $5 \mathrm{~Hz}$ when the dry/wet ratio was 0.5 .

contact of reactants and slowed down corrosion. The increase of the stress intensity factor amplitude led to the increase of crack opening, which made the substances produced by corrosion in the opening were easier to be washed away by the flowing sea water and continued corrosion reaction. It can be noted from Figs. 5 and 6 that the dry and wet alternation had the largest influence on the expansion rate at the stage of the low stress intensity factor amplitude, which was because that the leading factor of the crack growth rate was corrosion at that time and one of the factors affecting the corrosion rate was the dry and wet alternation.

\section{Conclusions}

In this study, the corrosion fatigue crack growth rate was tested using three-point bending method and electro-hydraulic servo test machine when the loading frequency was $0.3 \mathrm{~Hz}, 1.5 \mathrm{~Hz}$ and $4 \mathrm{~Hz}$, respectively. The environment under each frequency was air, sea water, dry/wet ratio at 1 and $\mathrm{dry} /$ wet ratio at 0.5 . The following results were obtained.

Under the same stress load frequency, the dry/wet ratio had a great influence on the crack growth rate at the stage of low stress intensity factor amplitude when the loading frequency was $0.3 \mathrm{~Hz}$, but the influence of the dry/wet ratio decreased with the increase of the stress intensity factor amplitude and finally tended to be consistent. The influence of the dry/wet ratio on the crack growth rate at the stage of low stress intensity factor amplitude decreased when the loading frequency was $1.5 \mathrm{~Hz}$

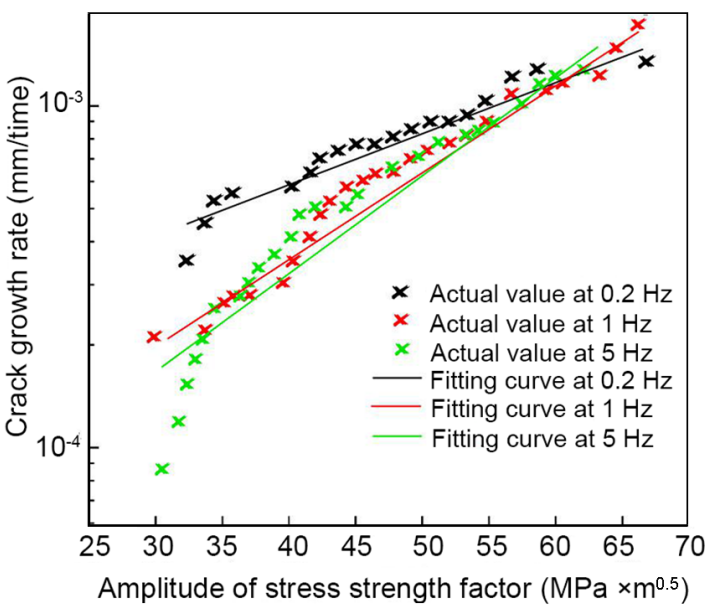

Fig. 6. The growth rate of cracks under loading frequency of $0.2,1$ and $5 \mathrm{~Hz}$ when the dry/wet ratio was 1 .

than that when the loading frequency was $0.3 \mathrm{~Hz}$. The influence of the $\mathrm{dry} /$ wet ratio on the expansion rate under different amplitudes of stress intensity factors was the same as that when the loading frequency was $0.3 \mathrm{~Hz}$. When the loading frequency was $4 \mathrm{~Hz}$, the influence of the dry/wet ratio on the crack growth rate was not obvious; and the expansion rate was basically the same when the dry/wet ratio was 1 and 0.5 . There was a critical dry/wet ratio; under the dry/wet ratio, the fatigue crack growth rate was larger than that in seawater in the stage of low stress intensity factor amplitude.

Under the same dry/wet ratio, the crack growth rate under the low loading frequency was far greater than that under the high loading frequency in the stage of low stress intensity factor amplitude, but the differences between the rates under the high frequency were small. With the increase of the stress intensity factor amplitude, the growth rates of cracks under three loading frequencies tended to be close; the rates were basically consistent when the stress strength factor amplitude was larger than $55 \mathrm{MPa} \cdot \mathrm{m}^{0.5}$.

The results are important in determining the performance of the steel plate of the offshore platform.

\section{References}

1. W. Liu, R. G. Hunsperger, M. J. Chajes, et al., J. Mater. Civil Engin., 14, 217 (2015).

2. J M Bastidas, E M Mora, S. Feliu, Mater. Corros., 41, 343,(2015).

3. D. Zhang, Y. Tang, S. Qi et al., Corros. Sci., 102, 517 (2016). 
4. F. Stern, Z. Wang, J. Yang et al., J. Hydrodyn., 27, 1 (2015).

5. P. Rajala, L. Carpen, M. Vepsalainen, M. Raulio, et al., Front. Microbiol., 6, 647 (2015).

6. B. N. Grgur, A. R. Elkais, M. M. Gvozdenovic et al., Prog. Org. Coat., 79, 17 (2015).

7. M. Mehdipour, B. Ramezanzadeh, S. Y. Arman, J. Ind. Eng. Chem., 21, 318 (2015).

8. M. Dudukcu, Mater. Corros., 62, 264 (2015).

9. J. Tong, K. Zhang, S. Lin. W. Wang, Trans. China Weld. Inst., 2015.
10. W. Morgner, C. Schnitger, et al. 46 (2017).

11. T. Abe, Key Eng. Mater., 725, 226 (2016).

12. A. Indriani, Y. Witanto, A. S. Pratama et al., Mater. Sci. Eng. Confer. Series, 012022 (2018).

13. V V. Usov, E E. Gopkalo, N. M. Shkatulyak et al., Metallurgiya, 2015759 (2015).

14. Q. Dai, L. Meng, Z. Liang, J. J. Wu, et al., Trans. China Weld. Inst., (2015).

15. H. Miyazaki, Y. Zhou, S. Iwakiri, H. Hirotsuru, et al., Ceramics Int., (2018). 